\title{
EDITORIAL
}

\section{What Makes for a Valid Legal Argument?}

\author{
INGO VENZKE*
}

\section{INTRODUCTION}

Three intertwined threads run through many recent editorials of the Leiden Journal of International Law (LJIL). They tie together many debates within and beyond the board of editors. The threads are those of the Journal's plural identity, the conversation about methods, and the spicy theme of interdisciplinarity. ${ }^{\mathrm{T}}$ They are related for obvious reasons. Methodology forms one - not the only and perhaps not the foremost factor in assessing submissions. We need to have an idea of good methodology for such an assessment to be possible. At the same time such an idea must not go against the plurality of perspectives or the Journal's aspiration to provide a forum to new and possibly unsettling voices. Research that cuts across disciplines seems especially valuable in this regard. But it comes with its own methodological challenges and tests the Journal's identity which is - albeit plural- that of a Journal of international law. It is against the background of these intertwined threads that I wish to offer a discussion of a central question that mirrors these recent debates: What makes for a valid legal argument?

It strikes me that for a while now international law has been presented as a practice of arguing. ${ }^{2}$ At the same time, there is little engagement with what it means, to argue. ${ }^{3}$ That is surprising as much turns on it. While scholars and practitioners tend to converge on thinking about international law as an argumentative practice, they remain worlds apart depending on what they understand to be the nature of

* Board of Editors, Associate Professor, University of Amsterdam [i.venzke@uva.nl]. Many thanks to Tanja Aalberts, Jean d'Aspremont, Valerio Priuli, and Yannick Radi for their comments.

I See respectively, J. d'Aspremont and L. van den Herik, 'The Public Good of Academic Publishing in International Law', (20I2) 26 LJIL I; C. Stahn and E. de Brabandere, 'The Future of International Legal Scholarship', (20I3) 27 LJIL I; T. E. Aalberts, 'The Politics of International Law and the Perils and Promises of Interdisciplinarity', (2013) 26 LJIL 503.

2 See F. V. Kratochwil, Rules, Norms, and Decisions (I 989), especially at 238; D. Z. Cass, 'Navigating the Newstream: Recent Critical Scholarship in International Law', (I 996) 65 Nordic Journal of International Law 34I-83, 359-60 (summarizing that 'Newstream lawyers refer to law as a system of "linguistic maneuvers", or as a practice of argument rather than a system of rules'); M. Koskenniemi, From Apology to Utopia (2005, first published I989) (whose cover text even announces that ' $[$ t]his book presents a critical view of international law as an argumentative practice').

3 That holds true even for intriguing treatises on the issue, such as the recent collection of articles by J. Salmon, Droit International et Argumentation (20I4). The situation is not so different beyond the confines of international law, but notable exceptions include J. Habermas, Between Facts and Norms (I996) 223-9; D. Patterson, Law and Truth (I996), 2 I; R. Christensen and M. Sokolowski, 'Die Krise der Kommunikation und die Möglichkeit juristischen Argumentierens' in K. D. Lerch (ed.), Die Sprache des Rechts, Vol. 2 (2005) I05-54; and E. Feteris, Fundamentals of Legal Argumentation (1999). 
arguing. There is much to gain from a closer inquiry. Hans Wohlrapp submits on a general note that arguing becomes ever more important as the concept of truth continues to erode. If we do not agree on what is true, we argue about it - in law as in everyday life. But how can the practice of arguing aim to convince interlocutors of the truth of claims if that point of reference (truth) is unavailable or, in other words, if it forms the exact subject of the argument? Conversely, if truth is an unavailable reference point, how can arguments be assessed? There might then be no arguments at all, but competing opinions alone. ${ }^{4}$ The question would then not be what is true or worthy of acceptance, but what is, in fact, successful and accepted. Finally, what would the typically praised middle way look like that finds truth in what is consensually or conventionally seen to be true, and to what extent does it help to understand the nature of arguing? Asking what makes for a valid - rather than a true or successful - legal argument already comes with a programmatic suggestion in that latter direction, as I will show immediately.

\section{THE LOGIC OF DEDUCTION AND THE LURE OF RHETORIC}

When arguing aims to show the truth of propositions, one option might be to start from common grounds and to then see, in the tradition of studies of logic, which argument might make false inferences. There are many compelling challenges to such an approach, especially when it is employed to investigate the practice of legal argument, which uses the specialized natural language of the law, as opposed to formal languages such as algebra. Jürgen Habermas presents another route. He suggests testing the validity claims of arguments in argumentative practice itself. ${ }^{5}$ That is not without problems either as it rests on the questionable presumption of a prior understanding of the terms of the debate. ${ }^{6}$ Yet another option - which seems to already signal defeat - could be to show the truth of a legal argument by reaching out towards other kinds of disciplines with the hope of finding a solid foundation. But who is to say that the correct legal argument is the one that moral philosophy (justice), economic analysis (efficiency), or political science (power or prudence) requires? What is more, shifting the burden onto another discipline is likely to just expose similar disagreement and uncertainty on the terrain that, for a moment, was thought to be rock solid. Finally, the whole project of legal positivism was first and foremost driven to distinguish (international) law and its discourse from these disciplines.

As a result, there is a considerable disenchantment with attempts to find a baseline against which to assess the truth of arguments. I think that disenchantment is ever more visible in international law and is manifest in the now widespread use of the notion of interpretative communities. ${ }^{7}$ It is decidedly anti-foundationalist and

\footnotetext{
H. Wohlrapp, Der Begriff des Arguments (2008), 7-8.

J. Habermas, The Theory of Communicative Action, T. McCarthy transl. (I984).

J. Habermas, 'Zur Kritik der Bedeutungstheorie' in Nachmetaphysisches Denken (I 988), I05, I35.

Going back to the work of S. Fish, see in particular his Doing What Comes Naturally (I 989), especially at I4I-2.

The appeal is reflected in A. Bianchi, D. Peat, and M. Windsor, Interpretation in International Law (forthcoming, 20I4), see especially A. Bianchi 'The Game of Interpretation in International Law: The Players, the Cards and
} 
foregoes any attempt to articulate a yardstick for assessing the truth or correctness of (legal) arguments. Instead, it focuses on the reading of (legal) texts and shifts all emphasis onto the interpretative angle from which it is interpreted and, through its interpretation, produced. ${ }^{8}$ Whether a statement about the law is seen as correct now depends on whether interlocutors share a sufficiently similar approach as to how the law should be interpreted. ${ }^{9}$ Limits as to what can be said do not arise from what is true or valid but rather from what is accepted in a community of interpreters.

Such acceptance is explained by underlying choices about the proper ways and means of interpretation. This view, certainly, is not without critique and drawbacks either. ${ }^{\text {IO }}$ Among other things, it seems surprisingly static, as it offers no hint at how interpretative angles could change, and, relatedly, has little to say about why we continue to argue with one another in law as in everyday life. If everything boils down to a difference in approach, why bother? ${ }^{\text {II }}$ Finally, the core emphasis on an argument's actual acceptance within a community of interpreters leaves little room for the normativity of the law - for any account, that is, which backs up claims as to why anyone should act according to the law.

This last point is also one that troubles other accounts that embrace the appealing alternative view on the nature of arguing, which does not understand arguing as being aimed at showing the truth of propositions but at finding acceptance. To avoid misunderstanding: claiming that a statement about the law is true, or, in other words, that a legal argument is the correct one, is typically what everybody does in trying to find acceptance. But the question is not whether they are right, but whether they are persuasive and successful. Ralph Christensen and Michael Sokolowski nicely captured this feature when they speak of a public-relations approach to legal argument. The image is one of spreading opinions about the law through advertising and through membership promotion for one's club of the like-minded. Normativity is lost. Arguments about what is correct seem to surrender to the force of those in power. They can buy airtime and might drive others towards acceptance. ${ }^{\mathrm{I} 2}$

Views on the nature of legal argument are split between the logic of deduction and the lure of rhetoric. This is not the place to take a discussion of these oppositesand everything in-between - much further. It is just to say that my asking about the validity of legal argument, rather than about its truth or success, suggests three modest but in my opinion decisive points, each moving the debate a step away from the opposing extremes. First, the actual success of arguments hardly works as a justificatory reason. ${ }^{13}$ Placing much emphasis on factual acceptance is troublesome

Why the Game is Worth the Candle'. See also the concept's prominent place in J. d'Aspremont's editorial, 'Wording in International Law', (20I2) 25 LJIL 575.

8 S. Fish, 'What Makes an Interpretation Acceptable' in Is There a Text in This Class? The Authority of Interpretative Communities (I980), 338.

9 Though with decisive differences, the core idea is imbued with remnants of classical hermeneutics' thinking about the interpreter's Vorverständnis. See the seminal H.-G. Gadamer, Wahrheit und Methode (I 960).

Io See, e.g., for a particularly pointed critiques Patterson, supra note 3, at I I5-I 7; P. Schlag, 'Fish v. Zapp, The Case of the Relatively Autonomous Self', (I987) 76 Georgetown Law Journal 37.

I I See H.-J. Cremer, 'Völkerrecht - Alles nur Rhetorik?', (2007) 67 ZaöRV 267.

I 2 See Christensen and Sokolowski, supra note 3, at I I9-20.

I3 Granted, in the doctrine of international law, due to its continued reliance on consent in law-making, that is less clear as in other fields of law. 
for any account of an argumentative practice that is normative - such as law in the sense that it turns around what should be done. That requires justification, and invoking factual acceptance is simply a poor justification. Second, claims about truth tend to reach beyond the law to other disciplines. In contrast, asking about validity, I suggest, comes with an accent on the autonomy of the law and legal discourse. Everything from the outside needs to be translated and judged on the discipline's own standards for the validity of the arguments. What the standards of validity are can probably be gleaned from practice of that discipline alone. ${ }^{\mathrm{I} 4}$ They can only be gleaned from the argumentative practice that is international law. Third, the shift from success to validity comes with a shift from the actors in the practice of arguing to the arguments themselves. ${ }^{15}$ Among other things, this means that considerations connected to the clout of the actor recede further to the background. That does not make thinking about validity uncritical. It brings to the fore more structural predispositions concerning the standards of validity. These three points, which embolden the concept of validity in the inquiry of argumentative practice, bring me to issues of the balance between both theory and practice as well as to the spicy theme of interdisciplinarity.

\section{THEORY, PRACTICE, AND INTERDISCIPLINARITY}

The LJIL distributes articles into sections of 'International Legal Theory' and 'International Law and Practice'. As the record shows, the respective emphasis on theory or practice is typically one of degree. Articles mostly do best with a blend of both. We have published articles with a heavy leaning on moral and practical philosophy. But we typically encourage authors to show the implications of their arguments for international law, to take that extra step of translation. Conversely, other articles lean towards sociology in writing about international law. Yet others plough through a wealth of practice also in our legal theory section, but they do so with a theoretical ambition. This variety testifies to the plurality that we wish to maintain and cultivate.

What is more, these mixtures of theory and practice mirror different views of the nature of legal argument. What makes an argument right, successful, or valid? Thinking of arguing as establishing the truth or rightness of claims tends to bring international law closer to moral or political philosophy. Focusing on what makes opinions about the law spread - what, in fact, makes one claim prevail over another moves inquiries nearer to sociology. Indeed, if ages of critical thinking have taught us anything, then I believe it is that inquiries of what is morally compelling and actually accepted - what is normatively and sociologically legitimate -are intrinsically

I4 See Christensen and Sokolowski, supra note 3, at I43.

I5 I thank Valerio Priuli for articulating this point clearly. He is in the later stages of writing a doctoral thesis focusing on theories of arguing. I have had the pleasure and benefit of discussing parts of it. Do look out for the book. 
linked. ${ }^{16}$ Bearing that link in mind usually makes for the most rewarding studies even when they focus on either one or the other.

If, beyond rightness and success, the validity of international legal arguments can only be gleaned from the practice of arguing, then of course a very close analysis of that practice is needed. This last strand would give the concept of truth a pragmatic twist and call to be true that which is valid within a community of practice. ${ }^{17}$ It can thus connect with views on the nature of legal arguing, which place emphasis on actual acceptance. But it would do so with the disclaimer that there must be 'more to knowledge than "what our peers let us get away with saying"'. ${ }^{8}$

As editors, we let you get away with saying many different things, checked through our double-blind peer review processes. The argument counts, rather than the perspective or the author. Hence, what I do not want this editorial to convey, to be clear, is some kind of policy or catalogue of what I consider good and proper legal research. Even my own views are in any event curbed through exchanges with my co-editors and our peer reviewers. Luckily we differ. What I do want to convey is the modest suggestion that much more may be gained from a further investigation of the concept of arguing, now that it has become so commonplace to present international law as an argumentative practice. That view enjoys appeal because it suspends differences. They then resurface in a further investigation of the concept of arguing. Were does it lie between the logic of deduction and the lure of rhetoric? How about it? We would be happy to receive your submission, equally so when you do not agree with any or all of the above. After all, academic writing is no less an argumentative practice than law.

What amounts to a (very) good argument in an international law journal, finally, surely differs from what is a valid legal argument. Of course we are not only concerned with arguments of international law, but also just as much with arguments about it, especially in the international legal theory section. In particular those arguments about the law gain insights and borrow methodological tools from other disciplines, sometimes causing anxieties among lawyers who fear not only for their turf but also for the autonomy of their discipline. Since there is a minimal hope that the language of international law civilizes brute power, international law's fate might well be more than the idiosyncratic concern of some international lawyers. Yet, my co-editor Tanja Aalberts and I have both critiqued anxieties in the face of interdisciplinarity. ${ }^{\text {I9 }}$ The concern, notably, that some outside perspectives reduce legal normativity to causal explanations, cuts across disciplines. ${ }^{20}$ We continue to pursue our arguments on those anxieties elsewhere.

See J. Habermas, 'Legitimation Problems in the Modern State', in Communication and the Evolution of Society (I979), I78, 205.

I7 See Wohlrapp supra note 4, at 50-56.

I8 J. Friedrichs and F. Kratochwil, 'On Acting and Knowing: How Pragmatism Can Advance International Relations Research and Methodology', (2009) 63 International Organization 70I-3I, 706 with reference to R. Rorty, Philosophy and the Mirror of Nature (1980), I 76.

I9 See Aalberts, supra note I; I. Venzke, 'Multidisciplinary Reflections on the Relationship Between Professionals and the(ir) International Law', in N. Krisch, M. Prost, and A. van Aaken (eds.), European Society of International Law, Conference Paper Series (2013).

20 See, recently, F. Kratochwil, The Status of Law in World Society: Meditations on the Role and Rule of Law (2014), 55. 
Here I only want to note in closing that placing emphasis on an argument's validity in the practice of international law suggests that the standards of assessment continue to be those embedded in the argumentative practice itself. ${ }^{2 \mathrm{I}}$ They are based on distinct views as to what counts as competent performance. ${ }^{22}$ Asking about legal validity certainly differs from an outright concern for the justness or success of legal arguments. At the same time, it can open up avenues of research that links those concerns. It can explore, for instance, how ideas about that which is right or just, on the one hand, as well as the capacity of the powerful to induce acceptance, on the other, reverberate in standards of validity and vice versa. More specifically, it could see how standards for validity shift over time and how they absorb different convictions of what is right as well as different power relations. Those are grand themes, to be sure. What is more, at any moment it is intriguing to see how practice varies within international law. What counts as a valid legal argument in international criminal law, for instance, differs from what might count in international trade law. Asking about validity might push us further towards identifying and articulating the standards of our fragmented profession and its embedded assumptions. This would come with analytical purchase, if not with normative drive. ${ }^{23}$ Asking what makes for a valid legal argument enables us to learn more of international law and more about it.

2 I That is also the conclusion of Patterson, supra note 3.

22 See E. Adler and V. Pouliot, 'International practices', (20I I) 3 International Theory I-36, 4-8 (who define practice as 'competent performance'). Also see Habermas, supra note 3, 224; Koskenniemi, supra note 2, at 589 (the book's descriptive project 'was to reconstruct the argumentative architecture of international law in its many variations so as to produce an account of it as a language and a professional competence').

23 That is the recent argument of my other co-editor in the Journal's section on 'International Legal Theory', Y. Radi, 'In Defence of “Generalism” in International Legal Scholarship and Practice', (2014) 27 LJIL 303. 